area enclosed between the transverse line and the radial ray is dark reddish-brown. In addition to the two rays of the upper surface, there is a dark ray upon the lower side upon the second median. Expanse $q 55 \mathrm{~mm}$.

\section{Explanation of Plate 9.}

Fig. I. Cocoon-bag of Oecura Goodii, Holl. The dotted line indicates a portion removed for purposes of dissection.
Fig. 2. Cocoon-bag of Anaphe Moloneyi, Druce.

Fig. 3. Oecura Goodii, ठे, sp. n.

Fig. 4. Oecura Goodii, + , sp. n.

Fig. 5. Anaphe clara, ठ, sp. n.

Fig. 6. Anaphe subsordida, $q$, sp. n.

Fig. 7. Anaphe moloneyi, + , Druce.

Fig. 8. Anaphe infracta, $q$, Wls.

\title{
ON THE ATTRACTION OF LIGHT FOR THE TWO SEXES OF COLEOPTERA.
}

BY HENRY FREDERICK WICKHAM, IOWA CITY, IOWA.

Referring to the capture of moths, Dr. A. S. Packard writes, in a foot-note on page 246 of his "Entomology for Beginners," "It is a curious fact that in general the males alone are attracted to light; the same is probably true of beetles, especially the June beetle." As this statement does not agree very well with my own experience in collecting Coleoptera I have been led to go over a portion of my material and embody the results in the following table. With the exception of the specimens from Tucson, which were taken at street gas-lamps, all were captured at electric light.

Fifteen sets of insects have been examined. These are numbered in the table and $I$ have subjoined the locality in which each was taken as I find that a set from one locality will give a different proportion of a certain sex than that from another. With the imperfect data at hand it is impossible for me to determine what relation the date of capture may have to the proportion of either sex (since it sometimes happens that one sex appears somewhat earlier than the other) and I leave this for future studies. As a rule only a few days were spent at any one collecting point and the set of each species represents the work of two or three consecutive evenings, never of more than a week.

The insects have been taken at random from several different families, chiefly using genera, however, in which the male secondary sexual characters are sufficiently well developed to enable the sexes to be separated without too much trouble or chance of error.

Of these sets, those marked I, 3, 9, 12 are from Tucson, Arizona ; 2, 4, 5, Io, I5, from Albuquerque, New Mexico ; I3, I4, from Spokane Falls, Washington, all collected by myself. The remainder are from Lincoln, Nebraska 
and were kindly given me by Professor Shimek.

\begin{tabular}{|c|c|c|c|c|c|}
\hline 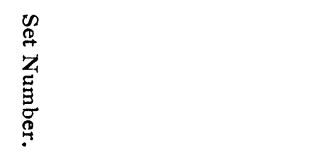 & 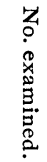 & 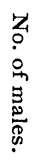 & 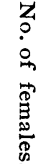 & 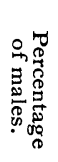 & 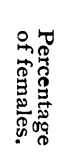 \\
\hline 1. Tetracha carolina. & 35 & 27 & 8 & $77 \cdot 1$ & 22.9 \\
\hline 2. Cicindela sperata. & 50 & 24 & 26 & & $5^{2}$ \\
\hline 3. Cicindela lemniscata. & 55 & 35 & 20 & 63.6 & 36.4 \\
\hline 4. Bledius armatus. & 10 & 3 & 7 & 30. & 70. \\
\hline $\begin{array}{l}\text { 5. Lachnosterna longitarsis. } \\
\text { 6. Lachnosterna fusca. }\end{array}$ & 9 & 5 & 4 & 55.6 & $44 \cdot 4$ \\
\hline $\begin{array}{l}\text { 7. Lachnost. crassissima. } \\
\text { 7. Lacnnosterna rusca. }\end{array}$ & $\begin{array}{r}150 \\
26\end{array}$ & $\begin{array}{r}108 \\
13\end{array}$ & $\begin{array}{r}42 \\
13\end{array}$ & $\begin{array}{l}72 . \\
50 .\end{array}$ & $\begin{array}{l}28 . \\
50 .\end{array}$ \\
\hline 8. Lachnosterna hirticula. & 20 & 17 & 3 & 85 & 15. \\
\hline 9. Cyclocephala (mixed set). & .45 & 36 & 9 & 80. & 20. \\
\hline 10. Cyclocephala immaculata. & .18 & 6 & 12 & $33 \cdot 3$ & 66.7 \\
\hline I I. Cyclocephala & 100 & o & 100 & o. & 100. \\
\hline I2. Chalepus obsoietus. & I30 & 33 & 97 & 25.4 & 74.6 \\
\hline 13. Frgates spiculatus. & 49 & 17 & $3^{2}$ & $34 \cdot 7$ & $65 \cdot 3$ \\
\hline rionus californicus. & 108 & 58 & 50 & 53.7 & $46 \cdot 3$ \\
\hline robasis atrivittata. & 25 & I8 & 7 & 72 . & 28. \\
\hline
\end{tabular}

In eight cases we find a preponderance of males; in six the females are more numerous, while in one case an equal number of each sex is found. In no instance is the set composed entirely of males, though the reverse has occurred once, and in a very large series.

It is worthy of note that many species which are usually considered strictly diurnal in habit are attracted a long distance by light-as, for example, a number of Cicindelae. Of the genus Cicindela I have taken lepida, punctulata and praetextata in such situations as well as the two mentioned in the table. No rule can be formulated in this case as to the attraction exerted on each sex - sometimes the males are more numerous, sometimes the females.

Several genera of Scarabaeidae, not here tabulated, show a varying proportion of femiles. Cheiroplatys clunalis, ${ }^{*}$ which appears in our Check-list under three specific names under the genera Aphonus and Orizabus, furnishes about equal numbers of each sex. Polyphylla is chiefly seen in the male sex and the same is true, so far as my experience goes, of Plectrodes.

It will be seen, then, from the foregoing notes, that captures of Coleoptera at light need by no means be confined to males only and that it can hardly be stated as a general rule that these alone are attracted.
Lepidopterological Notes. - It will please our readers to hear that $\mathrm{Mr}$. W. $\mathrm{H}$. Edwards has received a grant of $\$ 500$ from the Bache Fund of the National academy of sciences to complete the publication of his researches into the life histories of American butterflies.

One of the most zealous collectors of Indian Lepidoptera has been Col. Knyvett, who for many years has been in charge of the police forces in the province of Bengal and has utilized the native policemen in his entomological labors. His entire collection, numbering over 700 species of rhopalocera in splendid suites and nearly 2000 species of heterocera in equally fine suites, about 10,000 specimens, has been purchased at the suggestion of Dr. Holland by Mr. Andrew Carnegie. They will be under Dr. Holland's care and ultimately be placed in the museum which $\mathrm{Mr}$. Carnegie is building in Pittsburgh, Penn. The specimens have all been examined and named by the most eminent English specialists, Elwes, Hampson, Warren, Myrick and Butler.

Blatchley records 108 species of Indiana butterflies in a catalogue published in the 17 th report of the state geologist, 1892 .

* For the synonymy of this species see Mr. H. W. Bates in Biologia Centrali-Americana, Insecta, Coleoptera, Vol. II, part 2, p. 321 . 

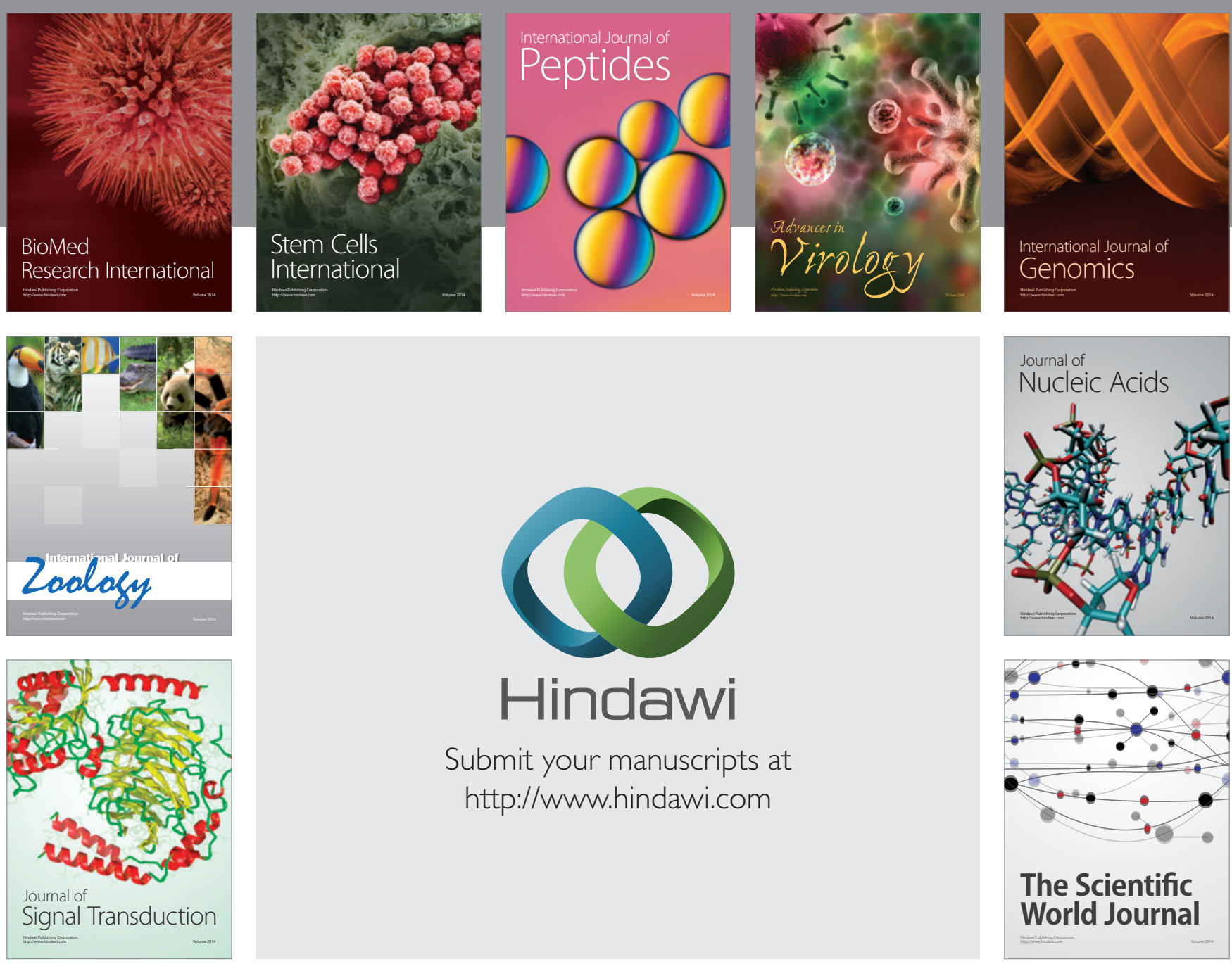

Submit your manuscripts at

http://www.hindawi.com
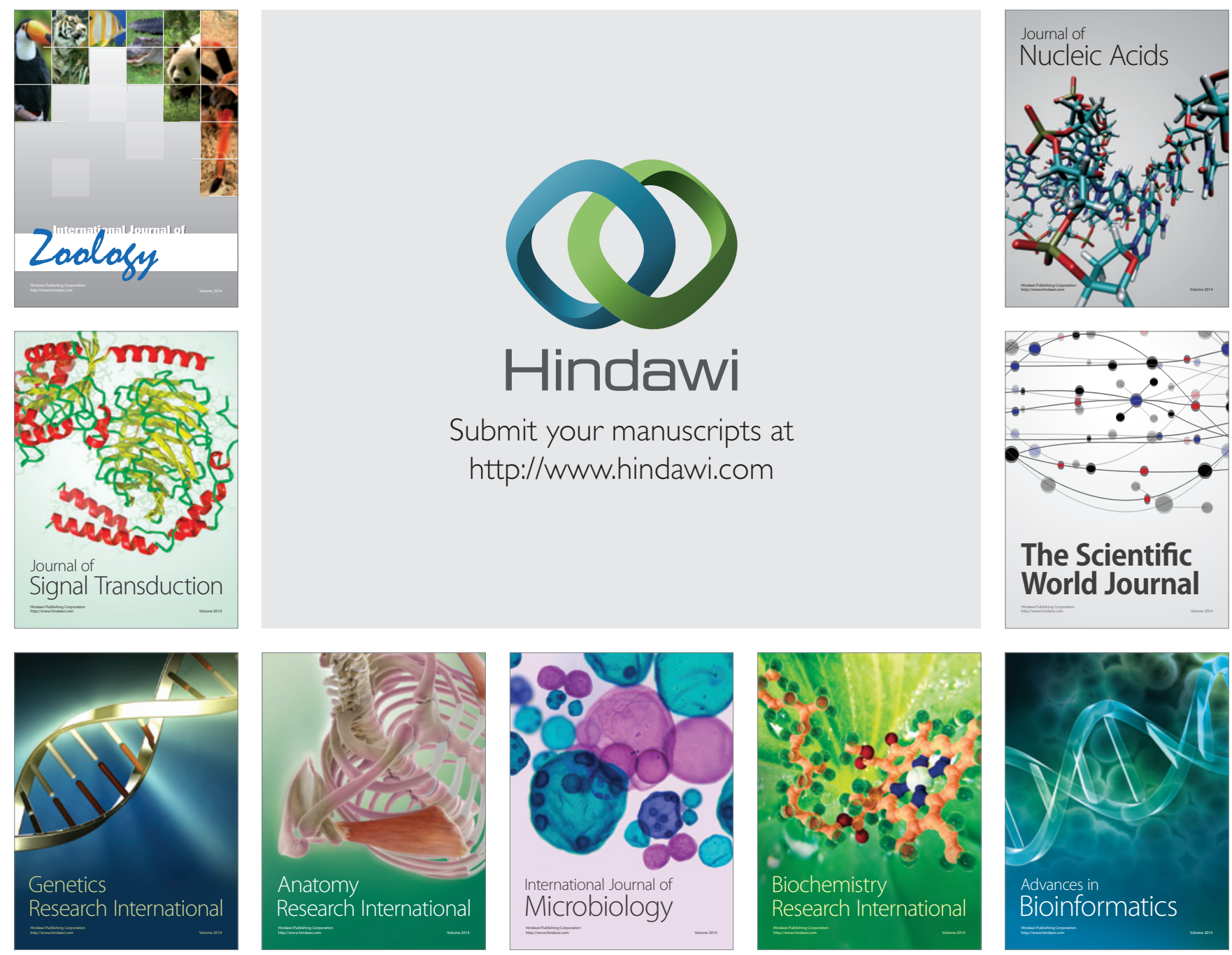

The Scientific World Journal
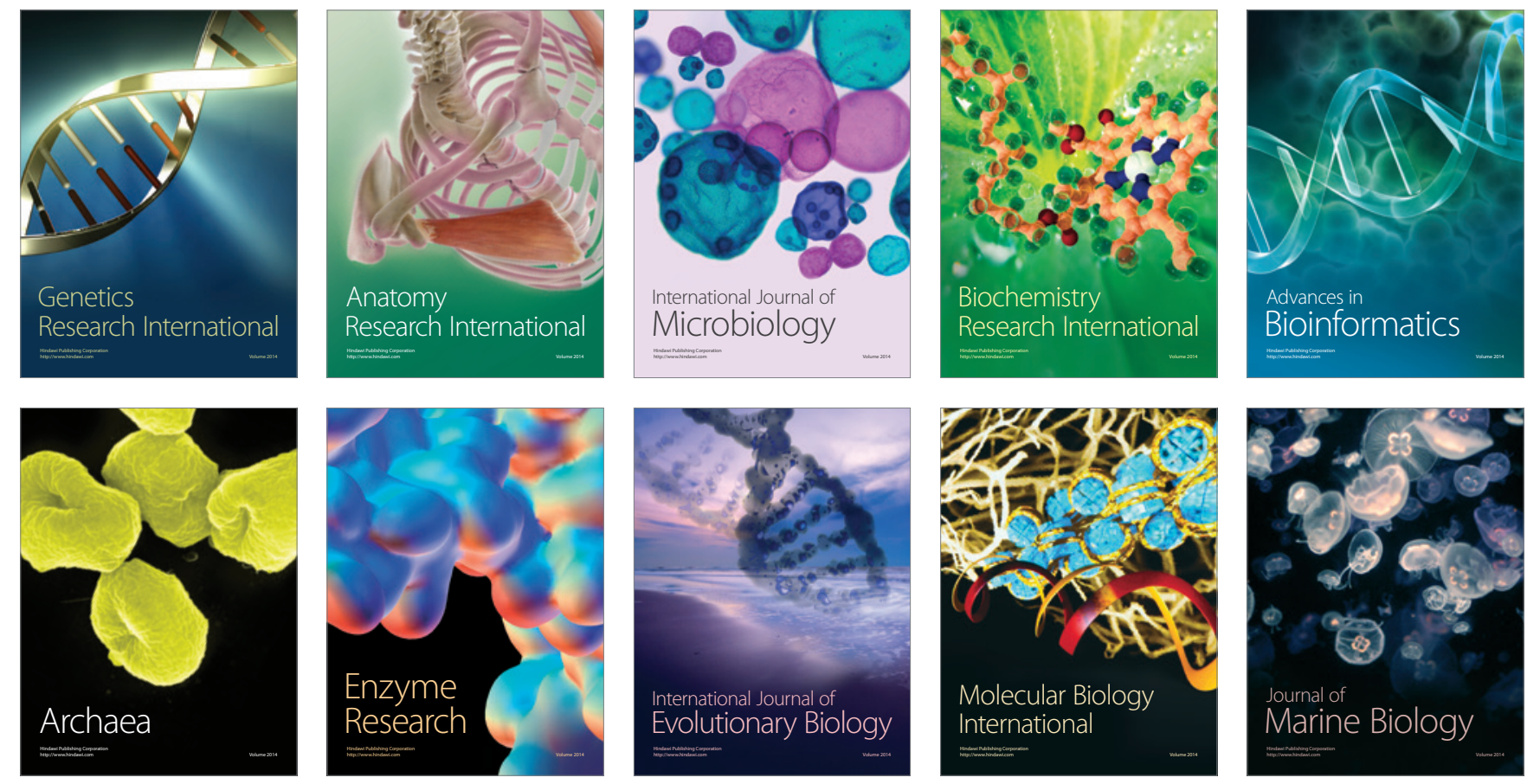